MaPan : Jurnal Matematika dan Pembelajaran

p-ISSN: 2354-6883 ; e-ISSN: 2581-172X

Volume 8, No 2, Dec 2020 (248-263)

DOI: https://doi.org/10.24252/mapan.2020v8n2a6

\title{
SELF-EFFICACY: ANALYSIS OF LEARNING OUTCOMES OF TEACHER EDUCATION PROFESSIONALS (PPG)
}

\author{
Darta1), Jusep Saputra') \\ 1,2Universitas Pasundan \\ 1,2Jl. Tamansari Nomor 6-8 Kota Bandung \\ E-mail: darta_pmat@unpas.ac.id1), jusepsaputrapmat@unpas.ac.id2)
}

Received April 30, 2020; Revised May 19, 2020; Accepted December 13, 2020

\begin{abstract}
:
Self-Efficacy (SE) is an essential component in mathematics learning that must be improved so that the teaching performance can convince students. The purpose of this study is how brightspace SPADA (Online Learning System) is developed to measure PPG participants' self-efficacy, which can contribute to the creation of an increase in the quality of education. This study's subjects were PPG participants in the Department of Mathematics Studies in one private LPTK in Bandung, which before the workshop began with online learning. The research method used is the Mixed Method of Embedded Design type and Embedded Experimental Model type. The instrument used was an online test on e-learning and a closed statement SE scale of 10 . The analysis used include, (1) Descriptive analysis of online learning outcomes and self-efficacy, (2) Comparative analysis of online learning outcomes between classes (Class A and B) using the Mann Whiney- $U$ test because the data are not normally distributed, (3) Comparative analysis of online learning outcomes between levels, namely junior high, high school, and vocational school (SMP, SMA, and SMK) using ANOVA, (4) Comparative analysis of self-efficacy between classes (Classes A and B) using t-test, because the data is normally distributed, (5) Comparative analysis self-efficacy between levels (SMP, SMA, and SMK) using ANOVA, (6) Analysis of the effect of online learning outcomes on self-efficacy using simple linear regression. The study results are: (1) Descriptive online learning results can be concluded that PPG Mathematics online learning outcomes are above average $(\geq 75)$, based on levels. The result of descriptive statistical data analysis of online learning outcomes is that the average value of participants from SMP, SMA, and SMK is 76.93, 93.12, and 85.92. PPG Mathematics participants' self-efficacy is in the very good category (8.6 from 0-10 intervals), based on the level. Descriptive statistical data analysis obtained the average value of participants from SMP, SMA, and SMK is 8.68, 8.65, and 8.76. (2) There is no significant difference in online learning outcomes between classes A and B. (3) There is no significant difference in online learning outcomes between SMP, SMA, and SMK. (4) There is no significant difference in self-efficacy between classes A and B. (5) There is no significant difference in self-efficacy between SMP, SMA, and SMK. (6) There is no online learning outcomes influence on Self-Efficacy.
\end{abstract}

Keywords: Self-Efficacy, Online, Learning Outcomes 


\title{
SELF-EFFICACY: ANALISIS HASIL BELAJAR DARING PESERTA PENDIDIKAN PROFESI GURU (PPG)
}

\begin{abstract}
Abstrak:
Self-Efficacy (SE) atau keyakinan diri merupakan komponen penting dalam pembelajaran matematika yang harus ditingkatkan, agar penampilan mengajarnya mampu meyakinkan siswa. Tujuan penelitian ini adalah bagaimana brightspace SPADA (Online Learning System) dikembangkan untuk mengukur self-efficacy peserta PPG, yang pada gilirannya dapat memberikan kontribusi terhadap terciptanya peningkatan mutu pendidikan. Subjek penelitian ini adalah peserta PPG dalam jabatan Bidang Studi Matematika di salah satu LPTK swasta di Kota Bandung yang sebelum kegiatan lokakarya dimulai dengan pembelajaran daring. Metode penelitian yang dilakukan adalah metode campuran (Mixed Method) tipe Embedded Design dengan jenis Embedded Experimental Model. Instrumen yang digunakan adalah tes online pada e-learning dan pernyataan tertutup SE skala 10. Analisis yang digunakan diantaranya, (1) Analisis secara deskriptif hasil belajar daring dan self-efficacy, (2) Analisis perbandingan hasil belajar daring antar kelas (Kelas A dan B) menggunakan uji Mann Whiney-U, (3) Analisis perbandingan hasil belajar daring antar jenjang (SMP, SMA, dan SMK) menggunakan ANOVA, (4) Analisis perbandingan self-efficacy antar kelas (Kelas A dan B) menggunakan uji-t, (5) Analisis perbandingan self-efficacy antar jenjang (SMP, SMA, dan SMK) menggunakan ANOVA, (6) Analisis pengaruh hasil belajar daring terhadap self-efficacy menggunakan regresi linear sederhana. Hasil penelitiannya adalah (1) Hasil pembelajaran daring secara deskriptif dapat disimpulkan bahwa hasil pembelajaran daring PPG Matematika di atas rata-rata ( $\geq 75)$, berdasarkan jenjang. Hasil analisis data statistika deskriptif hasil pembelajaran daring yaitu nilai rata-rata peserta dari SMP, SMA, dan SMK adalah 76.93, 93.12, dan 85.92. Self-efficacy peserta PPG Matematika ada pada kategori sangat baik (8,6 dari interval 0-10), berdasarkan jenjang. Analisis data statistika deskriptif diperoleh nilai rata-rata peserta dari SMP, SMA, dan SMK adalah 8.68, 8.65, dan 8.76, (2) Tidak ada perbedaan yang signifikan antara hasil pembelajaran online antara kelas A dan B, (3) Tidak ada perbedaan yang signifikan antara hasil pembelajaran online antara SMP, SMA, dan SMK, (4) Tidak ada perbedaan yang signifikan dalam self-efficacy antara kelas A dan B, (5) Tidak ada perbedaan yang signifikan dalam self-efficacy antara SMP, SMA, dan SMK, dan (6) Tidak ada pengaruh hasil belajar daring terhadap pada self-efficacy.
\end{abstract}

Kata Kunci: Self-Efficacy, Daring, Hasil Belajar

How to Cite: Darta, \& Saputra, J. (2020). Self-Efficacy: Analysis of Learning Outcomes of Teacher Education Professionals (PPG). MaPan : Jurnal Matematika dan Pembelajaran, 8(2), 248-263. https://doi.org/10.24252/mapan.2020v8n2a6. 


\section{INTRODUCTION}

7 -acher preparation as a profession is stated in Government Regulation Number 74 (PP No. 74) of 2008 concerning teachers. In addition to the teacher must be qualified S1, the teacher must have a professional certificate of educators obtained through professional education. Article 2 states that teachers must have academic qualifications, competencies, educator certificates, be physically and mentally healthy, and realize national education goals.

To realize the law mandate in preparing professional teachers, the government has prepared a Teacher Professional Education Program (PPG) in a PPG Study Program. In Indonesia, the PPG program follows the mandate of both the UUGD and Law Number 12 of 2012 on Higher Education, adopting a consecutive or layered model. Article 17 (1) of the Higher Education Law states that professional education is Higher Education after an undergraduate program that prepares students for work that requires special expertise requirements.

According to Kementerian Riset, Teknologi, dan Perguruan Tinggi (2017: 4), "The PPG Study Program is organized by universities that have a program of providing educators and educational staff who meet the requirements and obtain permits determined by the Minister of Research in Technology and Higher Education". Pasundan University (Unpas), especially the Faculty of Teacher Training and Education (FKIP) gaining trust as one of the LPTKs chosen to conduct the PPG Study Program. PPG Study Program held at FKIP Unpas are PPG Study Programs in the positions of Mathematics Education, Biology, Indonesian Language, and Economic Studies. This research was conducted in the field of mathematics studies in 2018.

According to the Directorate General of Learning and Student Affairs of the Ministry of Technology and Higher Education Research and the Directorate General of Teachers and Education Personnel of the Ministry of Education and Culture, the contents of the PPG curriculum are, 1) Workshops for the development of learning tools accompanied by strengthening pedagogical competencies or fields of study and professions, as well as research plans actions, 2) Field Experience Practices. Before the workshop takes place, the PPG In Position Program must carry out online learning through the Brighstspace application owned by the Belmawa Directorate. 
The problem faced by PPG participants is the confidence of each participant in completing the Knowledge Test at the end of the evaluation as a form of graduation later. From these problems, one of the online learning solutions is prepared to foster the confidence of PPG participants to be better prepared in facing the Knowledge Test. Online learning through the Brighstspace application is assumed to foster better PPG participants' Selfefficacy.

A person's academic performance is influenced by cognitive beliefs, including parents, teachers, and friends in their environment. Bandura (2008) reasoned that self-efficacy is the most important factor influencing one's cognition. Self-Efficacy (SE) for a teacher is very important to teach mathematics to his students. Whereas research on the SE of the final year students as prospective mathematics teachers in Indonesia, including those rarely done.

The study's focus is on how the brightspace was developed to measure PPG participants' self-efficacy, contributing to improving education quality. With adequate learning, a future generation of qualified and capable of contributing to society, the nation, and the state will emerge. According to Darta and Saputra (2018: 2), "The Director-General of Teachers and Education Personnel (GTK) reported that based on the results of the Teacher Competency Test (UKG) administered at the end of 2015, the average score was 53.02. The competencies tested are professional competence and pedagogic competency. Based on the data, it is still necessary to improve the quality of teachers in Indonesia".

Based on the formulation of the problems outlined earlier, this study aims to: (1) Determine whether PPG Mathematics Online learning outcomes are above average ( $\geq 75$ ). (2) Analyze differences in online learning outcomes of PPG Mathematics participants in Pasundan University in each class (class A and B). (3) Analyzing differences in online learning outcomes of PPG Mathematics participants in Pasundan University at every level, namely junior high, high school, and vocational school (SMP, SMA, and SMK). (4) Knowing whether PPG Mathematics participants' self-efficacy is in a good category. (5) Analyzing differences PPG Mathematics self-efficacy participants in Pasundan University each class (Class A and B). (6) Analyzing the differences in self-efficacy PPG Mathematics participants of FKIP Pasundan University every level (SMP, SMA, and SMK). (7) Analyzing the effect of online learning on self-efficacy.

Brightspace is an e-learning platform that teachers can use to learn and do assignments online. Enter the web address specified to access the Brightspace 
e-learning platform. Enter the username and password specified (obtained from the implementing LPTK). In this case, you as a student can only see the class you are taking, reading and downloading material, and working on an existing assignment or quiz (Effendi, 2018). According to Saputra (2017: 118), "Utilization of e-learning, in addition to an effort to overcome the technical problems of learning (learning media), is also an effort to answer the substantial problem of learning (teaching resources)".

Online learning is learning outside the classroom (wherever and whenever), because according to Suyadi in Maulana and Saputra (2018: 31), "Learning with the method of Outdoor Learning has the strengths, among others, 1) With varied learning students will be fresh thinking because a changing atmosphere, 2) inquiry is more productive, 3) acceleration is more integrated and spontaneous, 4) exploration ability is more coherent, and 4) fosters reinforcement of concepts". Besides, learning by using ICT has a positive influence. According to Yaniawati, Kartasasmita, and Saputra (2019: 2), "Utilization of e-learning in mathematics has positive influences. Other than as an effort in solving technical problems as learning media, this can also be an effort to address substantial learning problems as learning material.

According to Kementerian Riset, Teknologi, dan Perguruan Tinggi (2017: 2), the PPG Study Program is an educational program organized to prepare graduates of S1 Education and S1/DIV Non-Education who have the talent and interest to become teachers. This program aims to master teacher competence in full by following national education standards to obtain professional educators' certificates in early childhood education, primary education, and secondary education. The PPG Study Program is expected to answer various educational problems, such as: (1) shortage of teachers (shortage) especially in the outermost, frontier, and disadvantaged regions, (2) unbalanced distribution, (3) qualifications below standard (under qualification), (4) teachers who are less competent (low competence), and (5) mismatch between educational qualifications and the field that is supported (mismatched).

The PPG Study Program that will produce professional teachers is expected to produce superior and ready graduates to face the times' demands. The position of student learning outcomes in Indonesia is currently not encouraging. The 2015 PISA (Program for International Student Assessment) study shows that Indonesia has only been ranked 69 th out of 76 countries. The TIMSS study (Trends in International Mathematics and Science Study) also showed Indonesian students ranked 36th out of 49 countries to carry out 
scientific procedures (Kementerian Riset, Teknologi, dan Perguruan Tinggi, 2017: 2).

PPG Study Program is designed systematically and applies quality principles starting from selection, learning, and assessment processes, to competency testing. This program is expected to produce future professional teachers who can produce graduates who are superior, competitive, and of character, and love the motherland (Kementerian Riset, Teknologi, dan Perguruan Tinggi, 2017: 3).

The concept of self-efficacy stems from the theory put forward by Bandura around the 1970s taken from a social cognitive theory, which is usually associated with one's beliefs about their capabilities or beliefs in achieving specific goals. Efficacy is the affective domain. But efficacy is essential because it can influence the expected results or goals. Bandura in Setiadi (2010: 20) defines Self-efficacy as "Beliefs in one's capability to organize and execute the courses of action required to manage prospective situations". On another occasion, Bandura (2008) defines that self-efficacy is one's belief about his ability to influence the expected results.

\section{METHODS}

This study's research method is a Mixed Method of the Embedded Design type with the Embedded experimental model type. This model's main priorities are developed from quantitative and qualitative data that follows or supports the methodology. According to Creswell and Clark in Indrawan \& Yaniawati (2014: 84), next is the Embedded design.

The population in this study were participants of the PPG Study Program at the University of Pasundan Position. The sample was selected from the population by purposive sampling and was carried out considering that the researcher had a Mathematics Education background to examine PPG participants in Mathematics. The research sample was 58 participants of Phase 1 Mathematics PPG and 57 participants of Phase 2 Mathematics PPG.

Data analysis to test online data hypotheses and self-efficacy, then analyzed using descriptive statistics, normality tests, two-sample average comparison tests, and three-sample average comparison tests. Based on descriptive statistics, exploring the analysis obtained the maximum value, minimum value, average, standard deviation, and variance of the experimental and control classes. Furthermore, the data were analyzed qualitatively. Test online data normality and self-efficacy with the Shapiro-Wilk test. Online data 
analysis used was the Mann-Whitney test for comparison between classes A and $B$ because the data were not normally distributed. While the self-efficacy data analysis used is the t-test for comparison between classes A and B because the data is normally distributed. Online data analysis and self-efficacy used are ANOVA for comparisons between levels (SMP, SMA, and SMK). Effect of online learning outcomes on self-efficacy. The analysis used is a simple linear regression analysis with the $\mathrm{F}$ test.

\section{RESULTS AND DISCUSSION}

Brightspace SPADA (Online Learning System) Indonesia is one of the Directorate General of Learning and Student Affairs programs of the Ministry of Research, Technology, and Higher Education to develop PPG learning using the Hybrid Learning approach. This program consists of face-to-face learning and online learning through the Brightspace application.

Online learning is carried out by following the provisions of the PPG implementation guidelines. Online learning is held for 11 Weeks starting from June 09 until August 6, 2018. Online material includes Pedagogic and Professional Competencies. The study's online value data are only Professional Modules because they want to focus more on teachers' mathematics ability. The professional module (expertise) consists of 6 chapters (modules). Each module's contents are learning activities, assignments, formative tests, final projects, summative tests, and discussion forums. The expertise module starts on July 2, 2018 until August 17, 2018.

From the quota of 60 participants given by the Directorate General of Learning and Student Affairs, the Ministry of Research, Technology, and Higher Education, all passed. However, the study's data were 58 people because 2 people did not fill out the self-efficacy questionnaire. Research data analysis was taken from the grades of PPG Mathematics Education in 2018 Phase 1 of Class A and B. The following is the number of sample data used.

Table 1. Number of Research Sample Data by Class

\begin{tabular}{lrrrrrr}
\hline Class & \multicolumn{2}{c}{ Valid } & \multicolumn{2}{c}{ Cases } & \multicolumn{2}{c}{ Missing } \\
& N & Percent & N & Percent & N & Percent \\
\hline $20181 \mathrm{~A}$ & 30 & $100.0 \%$ & 0 & $0.0 \%$ & 30 & $100.0 \%$ \\
$20181 \mathrm{~B}$ & 28 & $100.0 \%$ & 0 & $0.0 \%$ & 28 & $100.0 \%$ \\
\hline
\end{tabular}


Based on table 1, the number of students who were the subject of research was 58 people consisting of class A with 30 people and class B with 28 people. If categorized by level, the amount of sample data is as follows.

Table 2. The Number of Research Sample Data by Level

\begin{tabular}{|c|c|c|c|c|c|c|}
\hline \multirow[t]{3}{*}{ Level } & \multicolumn{6}{|c|}{ Cases } \\
\hline & \multicolumn{2}{|c|}{ Valid } & \multicolumn{2}{|c|}{ Missing } & \multicolumn{2}{|c|}{ Total } \\
\hline & $\mathbf{N}$ & Percent & $\mathbf{N}$ & Percent & $\mathbf{N}$ & Percent \\
\hline SMP & 25 & $100.0 \%$ & 0 & $0.0 \%$ & 25 & $100.0 \%$ \\
\hline SMA & 10 & $100.0 \%$ & 0 & $0.0 \%$ & 10 & $100.0 \%$ \\
\hline SMK & 23 & $100.0 \%$ & 0 & $0.0 \%$ & 23 & $100.0 \%$ \\
\hline
\end{tabular}

Based on table 2, the number of students coming from SMP is 25 people, SMA is 10 people, and SMK is 23 people. Online data is taken from the final score of each student online. The maximum ideal score of a student is 100 . The following are the results of an analysis of online descriptive statistical data from both classes.

Table 3. Descriptive Statistics of PPG Online Values by Class

\begin{tabular}{|c|c|c|c|}
\hline \multicolumn{2}{|l|}{ Class } & Statistic & Std. Error \\
\hline \multirow{9}{*}{ 20181A } & Mean & 78.9540 & 2.75331 \\
\hline & Median & 85.4651 & \\
\hline & Variance & 227.422 & \\
\hline & Std. Deviation & 15.08050 & \\
\hline & Minimum & 17.63 & \\
\hline & Maximum & 89.82 & \\
\hline & Range & 72.19 & \\
\hline & Interquartile Range & 12.94 & \\
\hline & Skewness & -2.686 & .427 \\
\hline \multirow{11}{*}{ 20181B } & Kurtosis & 8.810 & .833 \\
\hline & Mean & 75.8648 & 3.98023 \\
\hline & Median & 84.1534 & \\
\hline & Variance & 443.582 & \\
\hline & Std. Deviation & 21.06139 & \\
\hline & Minimum & 3.95 & \\
\hline & Maximum & 87.83 & \\
\hline & Range & 83.89 & \\
\hline & Interquartile Range & 3.60 & \\
\hline & Skewness & -2.484 & .441 \\
\hline & Kurtosis & 5.460 & .858 \\
\hline
\end{tabular}


Based on the descriptive statistical analysis results from table 3, the minimum grades of $\mathrm{A}$ and $\mathrm{B}$ classes are 17.63 and 3.95. The maximum grades of classes A and B are 89.82 and 87.83 . The average grades of classes A and B are 78.95 and 75.86 . These results show that the average value of online class $A$ is higher than class $B$. When viewed from the standard deviation, classes A and $B$ are 15.08 and 21.06. Class B's standard deviation is greater than class A, meaning that class B's individual values are further than the average value compared to the individual values in class A than the average.

Table 4. Descriptive Statistics of PPG Online Values Based on Levels

\begin{tabular}{|c|c|c|c|}
\hline \multicolumn{2}{|c|}{ Levels } & Statistic & Std. Error \\
\hline \multirow{11}{*}{ SMP } & Mean & 76.9340 & 3.41578 \\
\hline & Median & 84.6320 & \\
\hline & Variance & 291.689 & \\
\hline & Std. Deviation & 17.07890 & \\
\hline & Minimum & 23.73 & \\
\hline & Maximum & 89.49 & \\
\hline & Range & 65.76 & \\
\hline & Interquartile Range & 12.50 & \\
\hline & Skewness & -2.105 & .464 \\
\hline & Kurtosis & 3.934 & .902 \\
\hline & Mean & 77.7360 & 6.80040 \\
\hline \multirow{7}{*}{ SMA } & Median & 85.5221 & \\
\hline & Variance & 462.454 & \\
\hline & Std. Deviation & 21.50474 & \\
\hline & Minimum & 17.63 & \\
\hline & Maximum & 88.70 & \\
\hline & Range & 71.07 & \\
\hline & Interquartile Range & 8.63 & \\
\hline \multirow{12}{*}{ SMK } & Skewness & -2.962 & .687 \\
\hline & Kurtosis & 9.032 & 1.334 \\
\hline & Mean & 77.9184 & 3.85893 \\
\hline & Median & 84.1713 & \\
\hline & Variance & 342.501 & \\
\hline & Std. Deviation & 18.50677 & \\
\hline & Minimum & 3.95 & \\
\hline & Maximum & 89.82 & \\
\hline & Range & 85.87 & \\
\hline & Interquartile Range & 4.03 & \\
\hline & Skewness & -3.283 & .481 \\
\hline & Kurtosis & 12.096 & .935 \\
\hline
\end{tabular}


If categorized by level from table 4 , the results of descriptive statistical data analysis of online learning outcomes are the average value of participants from junior high, high school, and vocational school is 76.93, 93.12, and 85.92. This result shows that the average online score descriptively from the highest order was achieved by participants from high school, vocational school, and junior high school. Learning material in Mathematics online is a level above S1. Participants from high school can more easily finish it because they are already familiar with more difficult Maths, followed by participants from SMK, and the last were participants from SMP.

Next, it's an analysis of online results comparison between class A and B in table 5. The analysis used is the Mann Whiney- $U$ test because the data are not normally distributed.

Table 5. Comparative Analysis of PPG Online Learning Outcomes between Classes

\begin{tabular}{lr}
\hline \multicolumn{2}{c}{ Test Statistics } \\
& daring math \\
\hline Mann-Whitney U & 328.000 \\
Wilcoxon W & 734.000 \\
Z & -1.432 \\
Asymp. Sig. (2-tailed) & .152 \\
a. Grouping Variable: class \\
\hline
\end{tabular}

In table 5, the significance value is $0.152>0.05$, so $\mathrm{H} 0$ is accepted. That is, there is no significant difference in online learning outcomes between classes $\mathrm{A}$ and $\mathrm{B}$. The results of the comparative analysis of online results between each level in table 6. The analysis used is the ANOVA Test.

Table 6. Comparative Analysis of PPG Online Learning Outcomes between Levels

\begin{tabular}{llcrrrr}
\hline $\begin{array}{l}\text { (I) } \\
\text { Levels }\end{array}$ & $\begin{array}{l}\text { Levels } \\
\text { Lifference } \\
\text { (I-J) }\end{array}$ & $\begin{array}{c}\text { Mean } \\
\text { Diff. Error }\end{array}$ & Sig. & $\begin{array}{c}\text { 95\% Confidence Interval } \\
\text { Lower }\end{array}$ & $\begin{array}{c}\text { Spper } \\
\text { Upound }\end{array}$ \\
\hline \multirow{2}{*}{ SMP } & SMA & -.80202 & 6.89884 & .908 & -14.6276 & 13.0236 \\
& SMK & -.98440 & 5.32720 & .854 & -11.6603 & 9.6915 \\
SMA & SMP & .80202 & 6.89884 & .908 & -13.0236 & 14.6276 \\
& SMK & -.18238 & 6.98401 & .979 & -14.1787 & 13.8139 \\
SMK & SMP & .98440 & 5.32720 & .854 & -9.6915 & 11.6603 \\
& SMA & .18238 & 6.98401 & .979 & -13.8139 & 14.1787 \\
\hline
\end{tabular}


In table 6 , all the significance values $>0.05$ so that $\mathrm{H} 0$ is accepted, i.e., there is no significant difference in online learning outcomes between junior high, high school, and vocational school. However, the results of descriptive online learning of PPG Mathematics online learning results are above average $(\geq 75)$.

The online math scores analysis shows no significant differences in online learning outcomes between classes A and B. There are no significant differences in online learning outcomes between junior high, high school, and vocational school. That is because online is open access. All participants can discuss and enable each other to help each other, meaning that the ability to do assignments and tests can be done by discussion and asking anyone. So it has an impact on the average value, which is almost the same for both classes.

Self-efficacy data is taken from the average questionnaire score of each student. The ideal maximum score of a student is 10 . The minimum grades of Class $A$ and $B$ are 8.76 and 8.65. The maximum value of class $A$ and $B$ is equal to 10.00 . The average grades of classes $\mathrm{A}$ and $\mathrm{B}$ are 8.76 and 8.65. These results show that the average self-efficacy of class $A$ is higher than Class B. If seen from the standard deviation, class A and B are 0.66 and 0.75. Class B's standard deviation is greater than class A means that the individual score in class B is further than the average value compared to the individual score in class $A$ than the average.

If categorized by level, then descriptive statistical data analysis obtained the average value of participants from junior high, high school, and vocational school is $8.68,8.65$, and 8.76 . This result shows that the average value of selfefficacy descriptively from the highest order was achieved by participants from SMK, SMP, and SMA.

Furthermore, a comparative analysis of self-efficacy between class A and $\mathrm{B}$. The analysis used is the t-test because the data are normally distributed

Table 7. Comparison Analysis of Self-Efficacy between Classes

\begin{tabular}{|c|c|c|c|c|c|c|c|c|}
\hline & & F & Sig. & $\mathbf{T}$ & df & $\begin{array}{l}\text { Sig. (2- } \\
\text { tailed) }\end{array}$ & $\begin{array}{c}\text { Mean } \\
\text { Difference }\end{array}$ & $\begin{array}{l}\text { Std. Error } \\
\text { Difference }\end{array}$ \\
\hline \multirow{2}{*}{$\begin{array}{l}\text { self- } \\
\text { efficacy }\end{array}$} & $\begin{array}{l}\text { Equal variances } \\
\text { assumed }\end{array}$ & .750 & .390 & .593 & 56 & .555 & .11000 & 18539 \\
\hline & $\begin{array}{l}\text { Equal variances } \\
\text { not assumed }\end{array}$ & & & .591 & $\begin{array}{r}54.0 \\
16\end{array}$ & .557 & .11000 & .18619 \\
\hline
\end{tabular}


In table 7 , the significance value is $0.555>0.05$ so that $\mathrm{H} 0$ is accepted, i.e., there is no significant difference in self-efficacy between classes A and B. Furthermore, a comparative analysis of self-efficacy between SMP, SMA, and SMK are conducted. The analysis used is ANOVA.

Table 8. Comparison Analysis of Self-Efficacy between Levels

\begin{tabular}{llccrrr}
\hline $\begin{array}{l}\text { Levels } \\
\text { Levels }\end{array}$ & $\begin{array}{l}\text { L) } \\
\text { Difference } \\
\text { (I-J) }\end{array}$ & Error & & & $\begin{array}{c}\text { Sig. } \\
\text { Lower } \\
\text { Bound }\end{array}$ & $\begin{array}{c}\text { 95\% Confidence Interval } \\
\text { Upper } \\
\text { Bound }\end{array}$ \\
\hline \multirow{2}{*}{ SMP } & SMA & .02933 & .26673 & .913 & -.5052 & .5639 \\
& SMK & -.07386 & .20597 & .721 & -.4866 & .3389 \\
SMA & SMP & -.02933 & .26673 & .913 & -.5639 & .5052 \\
& SMK & -.10319 & .27003 & .704 & -.6443 & .4380 \\
SMK & SMP & .07386 & .20597 & .721 & -.3389 & .4866 \\
& SMA & .10319 & .27003 & .704 & -.4380 & .6443 \\
\hline
\end{tabular}

In table 8 , all the significance values $>0.05$ so that $\mathrm{H} 0$ is accepted, i.e., there is no significant difference in self-efficacy between junior high, high school, and vocational school. In this study, PPG online is an independent variable that affects self-efficacy as a dependent variable. How to make a hypothesis decision: If p-value: If the sign value. $\mathrm{F}>0.05$, then $\mathrm{H} 0$ is accepted, which means there is no PPG online effect on self-efficacy.

There is no significant difference in self-efficacy between classes A and B. There is no significant difference in self-efficacy between SMP, SMA, and SMK. This result happens because all PPG participants have graduated online, so that all of them have high self-confidence to enter the next stage, which is the material learning workshop and learning tools.

According to Somakin (2010), someone who has a high SE certainly has high self-confidence and knows himself well. For students who have high selfconfidence, then the way to solve the given problem is not enough just one way but tried in various ways. Of course, someone who has a high SE will not stop studying, even if he has graduated. Akay and Boz (2010) state that SE has been a strong predictor of mathematical performance. In other words, the majority of research states that there is a positive relationship between attitude towards mathematics and success. 
Table 9. Analysis of the Effect of PPG Online on Self-Efficacy

\begin{tabular}{rlrrrrr}
\hline \multicolumn{1}{l}{ Model } & $\begin{array}{c}\text { Sum of } \\
\text { Squares }\end{array}$ & df & \multicolumn{1}{c}{$\begin{array}{c}\text { Mean } \\
\text { Square }\end{array}$} & F & Sig. \\
\hline \multirow{2}{*}{1} & Regression & .004 & 1 & .004 & .009 & $.925^{b}$ \\
& Residual & 28.046 & 56 & .501 & & \\
& Total & 28.051 & 57 & & & \\
\hline
\end{tabular}

a. Dependent Variable: self-efficacy

b. Predictors: (Constant), daring math

In table 9 , it can be seen that the sign value is $0.925>0.05$, meaning that $\mathrm{HO}$ is accepted. That is, there is no online learning outcomes influence on SelfEfficacy. This result can also be seen in the regression equation in table 10.

Table 10. Regression Equations

\begin{tabular}{|c|c|c|c|c|c|c|}
\hline \multirow{2}{*}{\multicolumn{2}{|c|}{ Model }} & \multicolumn{2}{|c|}{$\begin{array}{l}\text { Unstandardized } \\
\text { Coefficients }\end{array}$} & \multirow{2}{*}{$\begin{array}{c}\begin{array}{c}\text { Standardized } \\
\text { Coefficients }\end{array} \\
\text { Beta }\end{array}$} & \multirow[t]{2}{*}{$\mathbf{T}$} & \multirow[t]{2}{*}{ Sig. } \\
\hline & & B & Std. Error & & & \\
\hline \multirow[b]{2}{*}{1} & (Constant) & 8.745 & .411 & & 21.256 & .000 \\
\hline & $\begin{array}{l}\text { daring } \\
\text { math }\end{array}$ & .000 & .005 & -.013 & -.094 & .925 \\
\hline
\end{tabular}

a. Dependent Variable: self-efficacy

The value of the beta coefficient forms the simple linear regression equation. The formed equation model is: $Y=a+b X 1=8.745+0 X 1$. It is seen that the coefficient is zero, so the independent variable which is PPG online will not affect the dependent variable, namely self-efficacy.

The obstacles faced are as follows: (1) in online learning, some modules do not match what teachers teach at school to students, (2) online time is felt to be very short, and a lot of material is too difficult.

The findings of this study are consistent with some of the research findings put forward by Akay and Boz (2010) (in Darta, 2014; Somakin, 2010) some conclusions can be drawn as follows.

1. The teaching method significantly increases the confidence of prospective mathematics teachers.

2. The belief of prospective teachers in mathematical literacy is an essential predictor of faith in solving mathematical problems.

3. Self-efficacy is a structure that affects anxiety tests. Students who have high self-confidence test anxiety decreases. 
4. Self-efficacy, gender, and mathematics anxiety correlate with high significance to mathematics achievement. Age variables and general mental abilities are not significant. Mathematical self-efficacy is the best predictor of mathematical gains, followed by gender and anxiety.

5. Learning that is oriented to problem posing has a positive influence on improving attitudes toward mathematics and mathematics self-efficacy. In contrast, traditional learning is the opposite.

6. Self-efficacy has an indirect effect on mathematical achievement through goal setting. The explanatory style's significance with mathematical achievement shows that the style of explaining someone influences mathematics achievement.

Also, consistent with the research results by Holzberger, Philip, and Kunter (2013) found that emphasizing the importance of testing the teacher's self-efficacy is a cause and a consequence of the educational process. But contrary to the Unlu and Ertekin (2013) research results, it revealed that the preservice mathematics teacher's self-efficacy score of mathematics teaching and teaching mathematics is high. There is a positive relationship between the efficacy of teaching mathematics and self-efficacy in mathematics. Sharma (2014) found that self-efficacy must be relevant to understanding educational outcomes because self-efficacy leads to certain behaviors and motivations that can encourage or impede effective performance.

Concerning previous research linked to this study, although this study's results indicate no significant correlation between online learning outcomes and self-efficacy, it is still essential to foster PPG participants' self-efficacy. Besides, the weaknesses of online learning outcomes are that it is difficult to ascertain whether the learning outcomes displayed are actual learning outcomes or not. This condition is also a weakness of data collection online learning outcomes because PPG participants are difficult to control tightly.

\section{CONCLUSION}

This study's conclusions are: (1) Descriptive online learning results can be concluded that PPG Mathematics online learning outcomes are above average ( $\geq 75)$, based on levels. The results of descriptive statistical data analysis of online learning outcomes are the average value of participants from junior high, high school, and vocational school (SMP, SMA, and SMK) are 76.93, 93.12, and 85.92. PPG Mathematics participants' self-efficacy is in the very good category (8.6 from 0-10 intervals), based on the level. Descriptive statistical data 
analysis obtained the average value of participants from junior high, high school, and vocational school (SMP, SMA, and SMK) is 8.68, 8.65, and 8.76. (2) There is no significant difference in online learning outcomes between classes $\mathrm{A}$ and $B$. (3) there is no significant difference in online learning outcomes between the junior high, high school, and vocational school (SMP, SMA, and SMK). (4) There is no significant difference in self-efficacy between classes A and B. (5) There is no significant difference in self-efficacy between junior high, high school, and vocational school (SMP, SMA, and SMK). (6) There is no online learning outcomes influence on Self-Efficacy, with the formed equation model: $\mathrm{Y}=\mathrm{a}+\mathrm{b}$ X1 $=8.745+0 \mathrm{X} 1$.

\section{REFERENCES}

Akay, H., \& Boz, N. (2010). The effect of problem posing oriented analyses-II course on the attitudes toward mathematics and mathematics selfefficacy of elementary prospective mathematics teachers. Australian Journal of Teacher Education, 35(1), 1-17. https://doi.org/10.14221/ajte. 2010v35n1.6.

Bandura. (2008). Self-efficacy. Retrieved from http:/ / www.des.emory.edu/mfp /BanEncy.html.

Darta. (2014). Self efficacy dalam pembelajaran matematika. Symmetry 3 (Pendidikan Matematika), 3(1), 328-333.

Darta, \& Saputra, J. (2018). Indicators that influence prospective mathematics teachers representational and reasoning abilities. Journal of Physics: Conference Series, 948(1). https://doi.org/10.1088/17426596/948/1/ 012053.

Effendi, R. (2018). Brightspace: software e-learning bagi guru PPG dalam jabatan 2018. Kompasiana. Retrieved from https://www.kompasiana.com/ ridwaneffendi8466/5b15644abde57504a63ab092/e-learning-brightspace -untuk-guru-peserta-ppg-dalam-jabatan-2018.

Holzberger, D., Philipp, A., \& Kunter, M. (2013). How teachers' self-efficacy is related to instructional quality: A longitudinal analysis. Joumal of Educational Psychology. Joumal of Educational Psychology, 5(3), 774-786. https:// doi.org/10.1037/a0032198.

Indrawan, R., \& Yaniawati, P. (2014). Metodologi penelitian kuantitatif, kualitatif, dan campuran untuk manajemen, pembangunan, dan pendidikan. Bandung: PT Refika Aditama.

Maulana, G. G., \& Saputra, J. (2018). Penggunaan metode pembelajaran outdoor learning untuk meningkatkan hasil belajar siswa pada subkonsep vertebrata. BIOSFER: Jurnal Biologi Dan Pendidikan Biologi, 3(1), 30-33. https:// doi.org/dx.doi.org/10.23969/biosfer.v3i2.1263.

Saputra, J. (2017). Penggunaan model problem based learning berbantuan e-

262| Volume 8, No 2, December 2020 
learning terhadap kemandirian belajar mahasiswa pada dimensi tiga. KALAMATIKA Jurnal Pendidikan Matematika, 2(2), 117-130. https://dx. doi.org/10.22236/KALAMATIKA.vol2no2.2017pp117-130.

Setiadi, R. (2010). Self-efficacy in Indonesian literacy teaching context: a theoretical and empirical perspective. Bandung: Rizqi Press.

Sharma, H. L. (2014). Academic self-efficacy: A reliable predictor of educational performances. British Journal of Education, 2(3), 67-64. Retrieved from https://www.eajournals.org/journals/british-journal-of-educationbje/vol-2issue-3july-2014/academic-self-efficacy-reliable-predictoreducat ional-performances-2/.

Somakin. (2010). Peningkatan kemampuan berpikir kritis dan self-efficacy siswa sekolah menengah pertama dengan penggunaan pendekatan matematika realistik. Bandung: SPS UPI.

Kementerian Riset, Teknologi, dan Perguruan Tinggi. (2017). Pedoman penyelenggaraan pendidikan profesi guru. Jakarta: Ristekdikti.

Unlu, M., \& Ertekin, E. (2013). The relationship between mathematics teaching self-efficacy and mathematics self-efficay. 4th International Conference on New Horizon in Education, 106, 3041-3045. https://doi.org/10.1016/j. sbspro.2013.12.350.

Yaniawati, R. P., Kartasasmita, B. G., \& Saputra, J. (2019). E-learning assisted problem based learning for self-regulated learning and mathematical problem solving. Journal of Physics: Conference Series, 1280(4), 042023. https://doi.org/10.1088/1742-6596/1280/4/042023. 